\title{
PENGARUH DISIPLIN BELAJAR SISWA KELAS VIII-B SMP NEGERI I STABAT TERHADAP PEMBENTUKAN PERILAKU
}

\author{
Renfiani Dulyantina \\ Surel : dra.renfiani.dulyantina@gmail.com
}

\begin{abstract}
ABSTRAK
Penelitian ini bertujuan untuk mengetahui apakah terdapat pengaruh yang signifikan antara disiplin belajar dengan pembentukan perilaku di SMP Negeri 1 Stabat Kabupaten Langkat. Dengan meneliti dan memantau langsung suasana disiplin para siswa tersebut, penelitian ini dilakukan di dalam kelas serta terjun di lapangan SMP Negeri 1 Stabat Kabupaten Langkat. Subjek penelitian ini berjumlah 30 siswa (kelas VIII-B) yang keseluruhannya dijadikan sebagai sampel. Setelah mendapatkan data melalui angket maka penulis melakukan penelitian dengan menggunakan metode kuantitatif, yaitu pendekatan dengan menggunakan angka sebagai ukuran datanya dengan menggunakan rumus korelasi product moment. Tujuannya untuk memberikan deskripsi hubungan atau pelaksanaanya. Dari penelitian yang telah penulis lakukan maka sampailah kepada proses penarikan kesimpulan, sehingga terdapat korelasi yang sedang atau cukup antara pengaruh disiplin belajar siswa kelas VIII-B dengan pembentukan perilaku di SMP Negeri 1 Stabat Kabupaten Langkat. Hal ini berarti terdapat pengaruh disiplin belajar siswa dengan pembentukan perilaku.
\end{abstract}

Kata kunci : Disiplin, Belajar, Tingkah laku

\section{PENDAHULUAN}

Disiplin merupakan suatu gambaran yang menyatakan hasil kegiatan atau perubahan yang telah dicapai oleh seseorang melalui keuletan bekerja, baik secara kualitas maupun kuantitas dilihat dari pengukuran dan penglihatan dan penelitian atau hasil usaha tersebut. Dalam Kamus Besar Bahasa Indonesia (2002:268),disiplin adalah ketaatan (kepatuhan) kepada peraturan (tata tertib, dsb.) Dengan kata lain disiplin adalah sebuah penilaian yang memang menjadi standarisasi bagi keberhasilan tujuan pendidikan. Dengan disiplin seseorang akan mendapatkan cerminan dalam proses belajarnya, apakah dia termasuk ke dalam siswa yang baik yang secara otomatis bisa melanjutkan ke jenjang pendidikan berikutnya atau sebaliknya, akan menjadi siswa yang tidak baik karena tidak berdisiplin. Hal ini yang memicu semua komponen penunjang pendidikan diri mulai dari pengelola pendidikan, guru, dan siswa, untuk selalu meningkatkan mutu pendidikan terutamadisiplin. Dari sekian banyak faktor yang mempengaruhi mutu pendidikan, salah satunya adalah disiplin belajar. Keaktifan siswa dalam disiplin belajar dianggap sebagai sebuah jalan untuk mencapai perilaku dan prestasi yang baik dalam belajar. Siswa yang selalu di 

tempatkan sebagai objek baik suka ataupun tidak akan senantiasa meningkatkan keaktifan dalam belajar.

Bermacam - macam kegiatan yang dapat dilakukan oleh anak didik, baik melalui pendidikan formal maupun pendidikan di luar sekolah sehingga disiplin dalam pelaksanaanya berbeda dasarnya, disiplin itu ada yang didasari kehendak dan dorongan dari dirinya, dan ada juga tumbuh dan berkembang melalui orang lain maupun lingkungan di mana ia berada. Namun yang menjadi persoalan bagi kita adalah bagaimana agar disiplin belajar yang dilakukan anak didik itu sifatnya positif dan berhasil, dan juga dapat memberikan kemanfaatan baik bagi dirinya, keluarganya, lingkunganya, dan bangsa serta negaranya.

Disiplin belajar siswa dapat dimulai dari kebiasaan yang sering dilakukan di antaranya, siswa mampu mempergunakan waktu yang baik, memiliki rasa tanggung jawab terhadap tugas yang diberikan dan menyusun jadwal pelajaran.

Ada beberapa penyebab lain yang memperhambat perilaku siswa kurang baik, di antaranya kurangnya kedisiplinan belajar pada diri siswa serta kurangnya ketegasan sekolah dalam memberikan contoh perilaku yang baik. Dengan adanya kesadaran diri untuk melaksanakan disiplin belajar yang dilaksanakan sehari-hari dapat membuahkan hasil yang baik sesuai dengan tujuan pendidikan dan dalam penerapan disiplin memiliki keuntungan bagi peserta didik yaitu untuk hidup dengan kebiasaan yang baik, positif dan bermanfaat bagi dirinya sendiri dan lingkungannya. Pembiasaan dengan lingkungan sekolah mempunyai pengaruh positif bagi siswa untuk masa depan.

Untuk memberikan jawaban pada permasalahan-permasalahan tersebut di atas, maka penulis perlu memberikan perumusan masalah sebagai berikut:

a. Apakah terdapat pengaruh disiplin belajar siswa terhadap pembentukan perilaku siswa di kelas VIII-B SMP Negeri 1 Stabat Kabupaten Langkat.

b. Bagaimana pembentukan perilaku terhadap disiplin belajar siswa disekolah.

c. Apakah ada perbedaan terhadap siswa yang berdisiplin dan tidak berdisiplin terhadap pembentukanperilaku.

\section{METODE PENELITIAN}

Metode penelitian adalah pengetahuan berbagai metode yang digunakan dalam penelitian.Metode penelitian pada dasarnya merupan suatu metode ilmiah yang diartikan suatu cara yang dirancang serta diarahkan guna memecahkan suatu masalah yang dihadapi, yang dilakukan secara ilmiah, sistematis dan logis dengan menempuh suatu langkah-langkah tertentu. 
Pada penelitian ini, subjeknya berjumlah 30 siswa kelas VIII-B SMP Negeri 1 Stabat.

\section{HASIL PENELITIAN DAN PEMBAHASAN}

Pemecahan yang dimaksudkan bisa merupakan jawaban terhadap suatu masalah, atau bisa juga berupa kerangka pemikiran untuk menentukan hubungan antara dua variabel yang menjadi fokus dalam penelitian.

Instrumen yang digunakan untuk mengumpulkan data dalam penelitian ini adalah :

Observasi adalah "Pengamatan dan pencatatan yang sistematis terhadap gejala yang diteliti."Observasi ini dilakukan untuk memperoleh gambaran yang menyeluruh mengenai kondisi objek yang sedang diteliti dalam penelitian ini penulis mengadakan observasi di SMP Negeri 1 Stabat Kabupaten Langkat.

Angket adalah "Daftar pertanyaan yang diberikan kepada responden baik secara langsung maupun tidak langsung. "Angket disebarkan kepadasemua siswa kelas VIII yang sudah dibagi secara acak dengan jumlah 30 orang siswa SMP Negeri 1 Stabat guna mengetahui bagaimana pengaruh disiplin belajar siswa dengan pembentukan perilaku itu sendiri.

Wawancara adalah "Tanya jawab lisan antara dua orang atau lebih secara langsung”.Wawancara ini digunakan untuk melengkapi data angket dan observasi. Penulis melakukan wawancara kepada rekan-rekan guru guna mengetahui pelaksanaan fungsinya sebagai pengajar terhadap pemberian layanan kepada siswa yang berkaitan dengan disiplin belajar.

\section{Pembahasan}

Angket Variabel (x) tentang Disiplin Belajar SiswaTabel 1: Siswa hadir di kelas dan belajar sebagai kewajibannya.

\begin{tabular}{|l|c|c|c|c|}
\hline \multirow{2}{|c|}{ indikator angket } & \multicolumn{3}{|c|}{ alternatif jawaban } \\
\cline { 2 - 5 } & selalu & sering & $\begin{array}{l}\text { kadang- } \\
\text { kadang }\end{array}$ & $\begin{array}{c}\text { tidak } \\
\text { pernah }\end{array}$ \\
\hline $\begin{array}{l}\text { Siswa hadir di kelas dan belajar sebagai } \\
\text { kewajibannya }\end{array}$ & $56,7 \%$ & $13,3 \%$ & $30 \%$ & $0 \%$ \\
\hline Siswa berada di kelas sebelum guru datang & $30 \%$ & $10 \%$ & $53,3 \%$ & $6,7 \%$ \\
\hline $\begin{array}{l}\text { Siswa hadir di Kelas Walaupun Guru tidak } \\
\text { hadir }\end{array}$ & $16,7 \%$ & $10 \%$ & $63,3 \%$ & $10 \%$ \\
\hline Siswa Menjaga Kebersihan Kelas & $26,7 \%$ & $13,3 \%$ & $43,3 \%$ & $16,7 \%$ \\
\hline $\begin{array}{l}\text { Siswa Membaca dengan Cermat Ketika akan } \\
\text { Ujian }\end{array}$ & $36,7 \%$ & $10 \%$ & $50 \%$ & $3,3 \%$ \\
\hline $\begin{array}{l}\text { Siswa Mengulang Kembali Pelajaran } \\
\text { Sekolah di Rumah }\end{array}$ & $10 \%$ & $6,7 \%$ & $60 \%$ & $23,3 \%$ \\
\hline $\begin{array}{l}\text { Siswa Mempersiapkan Alat Tulis Sebelum } \\
\text { Berangkat ke Sekolah }\end{array}$ & $60 \%$ & $16,7 \%$ & $23,3 \%$ & $0 \%$ \\
\hline $\begin{array}{l}\text { Siswa mencatat hasil kesimpulan guru yang } \\
\text { menerangkan }\end{array}$ & $13,3 \%$ & $10 \%$ & $60 \%$ & $16,7 \%$ \\
\hline $\begin{array}{l}\text { Siswa datang tepat waktu sebelum pelajaran } \\
\text { di mulai }\end{array}$ & $40 \%$ & $16,7 \%$ & $43,3 \%$ & $0 \%$ \\
\hline $\begin{array}{l}\text { Siswa Meminta Izin Ketika Terlambat } \\
\text { Masuk Kelas }\end{array}$ & $16,7 \%$ & $13,3 \%$ & $40 \%$ & $30 \%$ \\
\hline Siswa memakai atribut sekolah lengkap & $30 \%$ & $10 \%$ & $33,3 \%$ & $26,7 \%$ \\
\hline Siswa datang ke sekolah tepat pada waktunya & $23,3 \%$ & $16,7 \%$ & $53,3 \%$ & $6,7 \%$ \\
\hline $\begin{array}{l}\text { Siswa membuat surat izin ketika tidak masuk } \\
\text { sekolah }\end{array}$ & $23,3 \%$ & $16,7 \%$ & $53,3 \%$ & $6,7 \%$ \\
\hline $\begin{array}{l}\text { Siswa memperhatikan pelajaran ketika guru } \\
\text { sedang menerangkan }\end{array}$ & $30 \%$ & $10 \%$ & $53,3 \%$ & $6,7 \%$ \\
\hline Siswa mengerjakan tugas yang guru berikan & $46,7 \%$ & $3,3 \%$ & $43,3 \%$ & $6,7 \%$ \\
\hline Siswa bertanya ketika tidak mengerti & $13,3 \%$ & $20 \%$ & $50 \%$ & $16,7 \%$ \\
\hline $\begin{array}{l}\text { Siswa membawa buku pelajaran sesuai } \\
\text { jadwal }\end{array}$ & $73, \%$ & $6,7 \%$ & $16,7 \%$ & $3,3 \%$ \\
\hline $\begin{array}{l}\text { Siswa mengikuti Organisasi Siswa di } \\
\text { Sekolah }\end{array}$ & $20 \%$ & $6,7 \%$ & $53,3 \%$ & $20 \%$ \\
\hline
\end{tabular}

Dari 122able diatas dapat dilihat hasil angket. Angket Variabel Y (Pembentukan Perilaku). 


\begin{tabular}{|l|c|c|c|c|}
\hline \multicolumn{1}{|c|}{ indikator angket } & selalu & sering & $\begin{array}{c}\text { kadang- } \\
\text { kadang }\end{array}$ & $\begin{array}{c}\text { tidak } \\
\text { pernah }\end{array}$ \\
\hline Siswa mengatur waktu belajar agar efektif & $40 \%$ & $16,7 \%$ & $20 \%$ & $23,3 \%$ \\
\hline $\begin{array}{l}\text { Siswa Bersikap Berhati-Hati dalam Memahami } \\
\text { Pelajaran }\end{array}$ & $30 \%$ & $16,7 \%$ & $53,3 \%$ & $0 \%$ \\
\hline $\begin{array}{l}\text { Siswa meninggalkan hal-hal yang menarik } \\
\text { pada kesia-siaan }\end{array}$ & $16,7 \%$ & $10 \%$ & $66,6 \%$ & $6,7 \%$ \\
\hline Siswa mengurangi tidur untuk belajar & $6,7 \%$ & $20 \%$ & $66,6 \%$ & $6,7 \%$ \\
\hline Siswa menghormati keluarga, guru dan teman & $56,7 \%$ & $13,3 \%$ & $30 \%$ & $0 \%$ \\
\hline $\begin{array}{l}\text { Siswa bersikap sopan ketika guru menerangkan } \\
\text { pelajaran }\end{array}$ & $56,7 \%$ & $10 \%$ & $23,3 \%$ & $10 \%$ \\
\hline Siswa menghormati gurunya & $33,3 \%$ & $10 \%$ & $50 \%$ & $6,7 \%$ \\
\hline Siswa mengikuti nasihat guru & $20 \%$ & $16,7 \%$ & $50 \%$ & $13,3 \%$ \\
\hline $\begin{array}{l}\text { Siswa bergegas lebih awal untuk mendapatkan } \\
\text { ilmu }\end{array}$ & $30 \%$ & $0 \%$ & $53,7 \%$ & $16,7 \%$ \\
\hline $\begin{array}{l}\text { Siswa berakhlak baik terhadap teman- } \\
\text { temannya }\end{array}$ & $23,3 \%$ & $20 \%$ & $46,7 \%$ & $10 \%$ \\
\hline $\begin{array}{l}\text { Siswa bersalaman ketika bertemu teman di } \\
\text { jalan }\end{array}$ & $20 \%$ & $6,7 \%$ & $53,3 \%$ & $20 \%$ \\
\hline Siswa berkata dengan jujur & $10 \%$ & $3,3 \%$ & $80 \%$ & $6,7 \%$ \\
\hline Siswa mencontoh yang baik pada temannya & $20 \%$ & $3,3 \%$ & $66,7 \%$ & $10 \%$ \\
\hline Siswa menghargai pendapat temannya & $20 \%$ & $20 \%$ & $50 \%$ & $10 \%$ \\
\hline Siswa mengikuti kegiatan keagamaan di rumah & $43,3 \%$ & $10 \%$ & $40 \%$ & $6,7 \%$ \\
\hline $\begin{array}{l}\text { Siswa mengikuti kegiatan sosial di sekolah } \\
\text { atau di rumah }\end{array}$ & $13,3 \%$ & $26,7 \%$ & $53,3 \%$ & $6,7 \%$ \\
\hline $\begin{array}{l}\text { Siswa mengikuti kegiatan keagamaan } \text { di } \\
\text { sekolah }\end{array}$ & $33,3 \%$ & $20 \%$ & $30 \%$ & $16,7 \%$ \\
\hline
\end{tabular}

\section{SIMPULAN}

Berdasarkan hasil penelitian yang dilakukan dan pembahasan yang telah penulis paparkan pada bab sebelumnya maka kesimpulan yang diperoleh dalam penelitian ini adalah sebagai berikut :

a. Pembentukan perilaku di sekolah akan tercapai dengan baik jika disiplin belajarnya juga baik, karena perilaku yang baik cerminan dalam berdisiplin belajar yang baik dan juga didukung oleh segenap komponen sekolah terutama kepala sekolah yang mempunyai wewenang untuk membuat peraturan dan tata tertib.

b. Perbedaan antara siswa yang berdisiplin dengan yang tidak dilihat dari perilaku mereka di sekolah, jika mereka taat terhadap peraturan maka dikatakan disiplin jika melanggar maka mereka tidak disiplin.

\section{DAFTAR RUJUKAN}

Ahmadi, Abu dan Rohani Ahmad. 2002. Pengelolaan Pengajaran. Jakarta: Bina Aksara.

Achin, Amir. 1990. Pengelolaan Kelas dan Interaksi Belajar Mengajar. Ujung Pandang: IKIP Ujung Pandang Press.

Margono, S. 2004. Penelitian Pendidikan. Jakarta: Rineka Cipta, Cet Ke-4

Poerwadarminta, W.J.S. 1985. Kamus Besar Bahasa Indonesia. Jakarta: Balai Pustaka.

Purwanto, Ngalim. 1984. Psikologi Pendidikan. Bandung: CV. Remaja Karya.

Ratmaningsih, Neiny. 2012. Pendidikan Pancasila dan Kewarganegaraan Untuk SMU Kelas 2.

Syah, Muhibbin. 1999. Psikologi Belajar. Jakarta: Logos.

Slameto. 1991. Belajar dan FaktorFaktor Yang Mempengaruhinya, Jakarta: Bina Aksara.

Soedijarto. $1989 . \quad$ Мепијu Pendidikan Yang Relevan dan Bermutu. Jakarta: Balai Pustaka.

Usman, Husaini. 2000. Metode Penelitian Sosial. Jakarta: BP. Aksara. 